УДК 656.022:656.081

УДОСКОНАЛЕННЯ УПРАВЛІННЯ ПРОЦЕСОМ ПРОСУВАННЯ ВАГОНІВ 3 НЕБЕЗПЕЧНИМИ ВАНТАЖАМИ НА ЗАЛІЗНИЧНІЙ МЕРЕЖІ

Д-р техн. наук Т.В. Бутько, магістр Т.М. Савчук

СОВЕРШЕНСТВОВАНИЕ УПРАВЛЕНИЯ ПРОЦЕССОМ ДВИЖЕНИЯ ВАГОНОВ С ОПАСНЫМИ ГРУЗАМИ НА ЖЕЛЕЗНОДОРОЖНОМ ТРАНСПОРТЕ

Д-р техн. наук Т.В. Бутько, магистр Т.Н. Савчук

\title{
IMPROVE THE MANAGEMENT OF THE MOVEMENT OF CARS DANGEROUS GOODS FOR RAILWAYS
}

Dr. tehn. science T.V. Butko, master T.M. Savchuk

У даній статті запропоноване вирімення науково-прикладного завдання, щодо обтрунтування організації і управління процесом перевезення небезпечних вантажів на мережі залізниць шляхом інтелектуальної підтримки планування на тактичному рівні, що забезпечує зменшення можливих ризиків. Формалізовано прочес планування маршрутів прямування вагонів з небезпечними вантажами на тактичному рівні у вигляді двоетапної математичної моделі вибору найбільш безаварійного маршруту прямування вагонів з небезпечними вантажами.

Ключові слова: небезпечний вантаж, ризик, аналіз дослідження, використання процедури Йєна-Флойда

В данной статье предложено решение научно-прикладной задачи по обоснованию организации и управления проиессом перевозки опасных грузов на сети железных дорог путем интеллектуальной поддержки планирования на тактическом уровне, обеспечивающей уменьшение возможных рисков. Формализован прочесс планирования маршрутов следования вагонов с опасными грузами на тактическом уровне в виде двухэтапной математической модели выбора наиболее безаварийного маршрута следования вагонов с опасными грузами.

Ключевые слова: опасный груз, риск, анализ исследования, использование процедуры ЙенаФлойда.

This paper proposes a solution of scientific and applied tasks to justify the organization and management of transport of dangerous goods on railway network by intellectual support planning at the 
tactical level, which would reduce the risks. Formalized planning process route cars with dangerous goods at the tactical level in two landmark mathematical model of choosing the least accident-free route cars with dangerous goods.

Key words: dangerous freight, risk, analysis of the study, using Yen-Floid's procedure.

Актуальність теми. В умовах розвитку транспортного ринку в сегменті організації перевезень небезпечних вантажів перед залізничним транспортом постає задача надання якісних послуг з перевезення за умови високого рівня безпеки перевізного процесу i забезпечення мінімальних витрат на здійснення перевезень.

Вступ. Упродовж 2011-2013 pp. відбувається зростання обсягів перевезень небезпечних вантажів, за різними оцінками, 3 середнім значенням 250-350 тис. тонн на рік на фоні $80 \%$ зносу основних фондів залізничного транспорту i дуже повільних темпів їх поновлення , поряд 3 цим спостерігається тенденція зростання транспортних подій за участю небезпечних вантажів різних класів небезпеки. Аналіз причин аварій і катастроф показав, що значна частка їх припадає на організаційні чинники, зокрема на неправильні дії диспетчерського персоналу та працівників станції - порушення вимог безпеки під час експлуатації рухомого складу та об'єктів інфраструктури залізничного транспорту, невиконання вимог інструкцій з безпеки руху при здійсненні поїзної та маневрової роботи. Дана ситуація вимагає вирішення задачі підвищення рівня безпеки при організації перевезень небезпечних вантажів на основі розробки раціональної технології управління їх перевезень на рівнях тактичного і оперативного планування.

Одним із найбільш складних етапів в організації перевезень небезпечних вантажів на залізничному транспорті $є$ процес планування маршруту слідування вагонів, який визначає 3 урахуванням діючого плану формування вантажних поїздів напрямок слідування та категорію поїзда, станції зупинки та розклад руху. Від рівня планування залежить безаварійність процесу перевезення небезпечних вантажів та ефективність реалізації якості заявлених послуг залізничним транспортом (точність доставки, швидкість за умови збереження вантажу).

Механізмом реалізації технології управління процесом просування вагонів 3 небезпечними вантажами на залізничній мережі $\epsilon$ впровадження сучасних інформаційно- керуючих систем, що пов'язано з необхідністю реалізації в об'єднаному комплексі автоматизованих робочих місць (АРM) диспетчерського персоналу системи підтримки прийняття рішень на основі розробки нових комплексів задач, інтегрованих в єдину автоматизовану систему керування вантажними перевезеннями (АСК ВП УЗ- $)$ ).

Аналіз наукових досліджень 3 організації процесу перевезень небезпечних вантажів на залізничному транспорті. У розвиток досліджень щодо розробки систем планування та оперативного управління на залізничному транспорті, технології організації перевезень небезпечних вантажів на залізничному транспорті, визначення оптимальних схем направлення вагонопотоків, застосування інформаційних технологій в управлінні експлуатаційною роботою, зробили великий внесок такі вчені та практики: H.C. Green, A.J. Bourne, R.E. Barlow, H. Kumamoto, F.N. Proschan, E.J. Henly, E. Apl, E. Erkut,

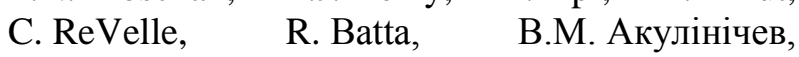
В.Н. Андросюк, А.Г. Базазьян, А.Л. Кармолін, А.В. Костров, П.С. Костров, П.С. Грунтов, В.М. Самсонкін, А.М. Островський, В.I. Медведєв, Л.Е. Шейнкман, С.І. Музикіна та ін.

Аналіз вітчизняних досліджень у галузі забезпечення безпеки залізничних перевезень довів, що в основі створення будь-якої нової технології перевезення небезпечних вантажів прийнято використовувати критерій підвищення безпеки руху. Кожна реалізація заходу для підвищення безпеки руху поїздів не враховує розміри витрат на реалізацію даного рівня безпеки та не зіставляється 3 економічною доцільністю їх впровадження. Поряд 3 цим у світовій науці і практиці техногенної безпеки введено і широко використовується поняття ризику, що дозволило перевести небезпеку в розряд категорій, що вимірюється. Застосування поняття ризику дозволило створити новий підхід до формування системи безпеки руху, яка повинна грунтуватись з позицій як безпеки, так і економіки.

Реалізація перевізного процесу, що пов'язаний з небезпечними вантажами, супроводжується ризиком несприятливих подій. 
Врахування ризиків при розв'язанні задачі обгрунтування процесу управління просуванням вагонів 3 небезпечними вантажами $\epsilon$ найбільш прийнятним підходом в роботах багатьох вітчизняних та закордонних вчених.

Метою даної роботи с удосконалення організації і управління процесом перевезення небезпечних вантажів на мережі залізниць шляхом інтелектуальної підтримки планування на тактичному рівні, що забезпечує зменшення можливих ризиків.

Викладення основного матеріалу. В умовах Львівської залізниці Рівненської дирекції було проведено статистичне дослідження щодо розподілу кількості вагонів 3 небезпечними вантажами. В результаті аналізу було доведено, що основними видами небезпечних вантажів $є$ міндобрива, хімікати, сода та інші. Для цієї номенклатури вантажів було отримано динаміку розподілу їх обсягу за місяцями року та добами окремих місяців.

Формалізація процесу пошуку маршрутів слідування вагонів 3 небезпечними вантажами на основі критеріїв мінімізації експлуатаційних витрат. За першим етапом розв'язання задачі на концептуальному рівні процес просування вагонів 3 небезпечними вантажами можна подати у вигляді графової структури $G=(V, E)$, в якій вершини $v_{\mathrm{i}}, v_{i} \in V$ слід розглядати як технічні станції залізничної мережі $(i=1, N$ - номер станції), а кожна дуга $e_{i j}, e_{i j} \epsilon E$ описує категорію $\mathrm{i}$ напрямок слідування вантажного поїзда $(j=1$, $N)$, в состав якого можливо включити вагони 3 небезпечними вантажами (дільничний, наскрізний тощо). По суті дуги графу визначають діючий план формування вантажних поїздів на полігоні залізничної мережі. Окрім етапу - слідування в складі поїзда, вагони 3 небезпечними вантажами проходять найбільш небезпечні операції 3 розформування-формування на технічних станціях, що слід враховувати в запропонованій графовій структурі. Для врахування даної умови в роботі запропоновано розбити вершини графу на декілька псевдовершин, які з'єднані дугами, що відповідають технологічним ланцюгам обробки вагонів на $i$ й технічній станції, тобто описують усі операції 3 вагонами від прибуття на станцію в складі поїзда відповідної категорії до відправлення в поїзді іншого напрямку 3 відповідною категорією. Це дозволяє перейти від графу $G=(V, E)$ до псевдографу $G^{\prime}=\left(V^{\prime}, E^{\prime}\right)$, $V^{\prime}$ - розширення множини вершин, що визначає початок та кінець операцій з вагонами на технічній станції, а множина $E^{\prime}-$ це розширена множина дуг, яка, крім напрямків прямування поїздів відповідних категорій, включає дуги, що відповідають технологічному ланцюгу обробки вагонів. Об'єднання напрямків прямування та технологічних ланцюгів обробки вагонів в єдину множину $є$ доцільним, так як вони мають єдину фізичну природу, а саме - час перебування вагонів на відповідних дугах. Внаслідок того, що розмірність псевдографу $G^{\prime}=\left(V^{\prime}, E^{\prime}\right)$ збільшується, доцільно прийняти наскрізну нумерацію, де $i=1, M$. Позначимо через $s$-вершину, що відповідає станції відправлення вагонів 3 небезпечними вантажами, а через $\mathrm{t}$ вершину, що $\epsilon$ станцією призначення відповідних вагонів (s, $\left.t, i, j \epsilon V^{\prime}\right)$ (рисунок).

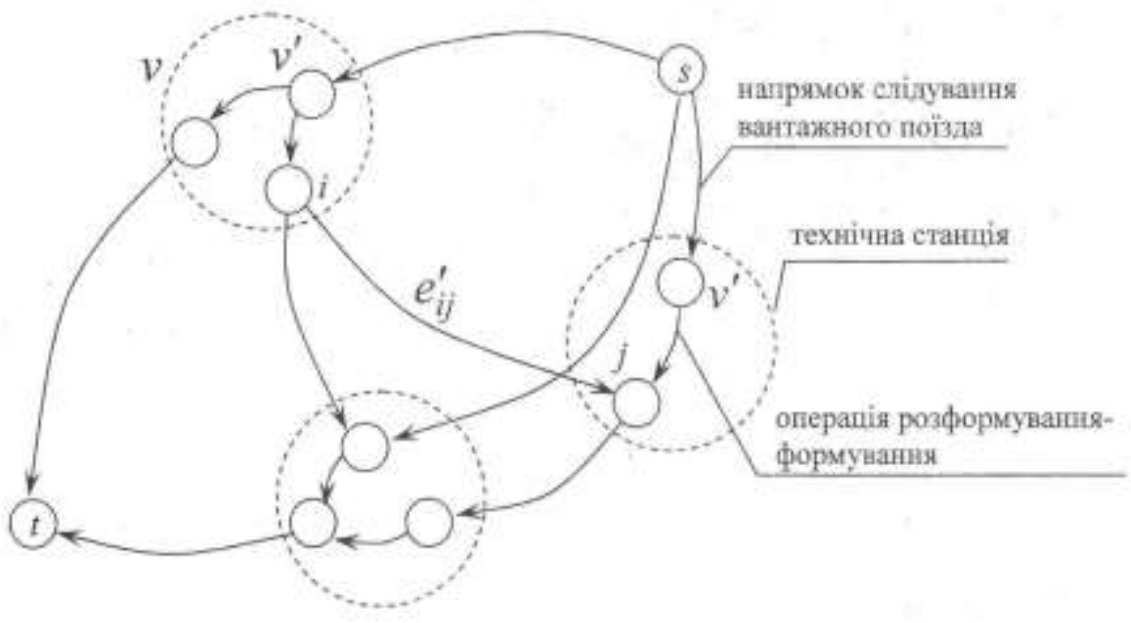

Рис. Граф залізничної мережі $\mathrm{G}^{\prime}=\left(\mathrm{V}^{\prime}, \mathrm{E}^{\prime}\right)$ 


\section{Експлуатація залізниць}

Для оцінки експлуатаційних витрат за маршрутом слідування вагонів запропоновано кожній дузі $e_{i j}{ }^{\prime}$ графу $G^{\prime}$ присвоїти параметр $c_{i j}$, що характеризує відповідно до опису дуги: вартість слідування вагонів в поїзді відповідної категорії або вартість проходження технологічного ланцюга обробки вагонів на технічній станції полігону мережі.

За таких умов критерієм ефективності вибору маршруту прямування вагонів 3 небезпечними вантажами $€$ мінімізація сумарних витрат щодо слідування вагонів у поїздах та обробки на станціях

$$
\left.\mathrm{F}=\sum_{i=1}^{\mathcal{M}} \sum_{j=1}^{\mathcal{M}} c_{i j} x_{i j} \rightarrow \begin{array}{c}
\text { min } \\
\left\{x_{i j}\right.
\end{array}\right\}
$$

та обмеження, що враховують безперервність маршруту, а кожен проміжний пункт на шляху проходження може бути відвіданий тільки один ра3:
- для перерахування всіх $k$ - дуг, що входять до $i$-ї вершини маршруту

$$
\sum_{\kappa}^{x_{k i}=1, i=2, M},
$$

- для перерахування всіх $j$-х дуг, що виходять із $i$-ї вершини маршруту

$$
\sum_{j} x_{i j}=1, i=1, M-1,
$$

Якщо ж $i$-та вершина не входить в найкоротший маршрут, то відповідна сума як для вхідних, так і вихідних дуг вершини графу повинна бути рівною нулю. Тоді для будьякого пункту мережі, крім початкового $\mathrm{i}$ кінцевого, повинна виконуватися умова

$$
\sum_{k} x_{\kappa i}-\sum_{j} x_{i j}=0 .
$$

У початковому пункті $\sum x_{s j}=1$, в кінцевому - $\sum x_{k t}=1, x_{i j} \geq 0$ для всіх $i, j$,

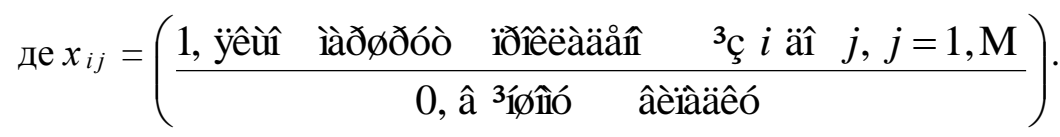

Транспортна система в задачі $\epsilon$ орієнтованим графом - двополюсною мережею, s - номер станції відправлення, $t$ - номер станції призначення $\mathrm{s}, t \in V^{\prime}$. Всі пункти маршруту можна розділити на початковий, проміжний i кінцевий. Очевидно, що в кожному проміжному пункті повинно бути по одній вхідній і вихідній дузі, а для початкового та кінцевого пунктів може бути тільки одна вихідна або вхідна дуга відповідно. Таким чином, обмеження (2 - 3) відображають вимогу про те, щоб у кожній вершині на маршруті із входу виходила лише одна дуга i y вхід заходила теж одна дуга. Обмеження (4) забезпечує рівність числа дуг, що входять та виходять в кожну проміжну вершину.

Використання критерію (1) та обмежень (2 - 4) дозволяє знайти найкоротший маршрут прямування вагонів 3 небезпечними вантажами від вершини $\mathrm{s}$ до $\mathrm{t}$, але для формування варіанта слідування вагонів за умови підвищеної надійності необхідним $\epsilon$ визначення на графі $\mathrm{G}^{\prime}$ декількох к - достатньо коротких простих шляхів (ланцюгів) 3 вершини відправлення до вершини прибуття.
Для виключення із множини можливих маршрутів неприпустимо складних та дорогих варіантів перевезення небезпечних вантажів необхідним $\epsilon$ дотримання умови неперевищення критичних експлуатаційних витрат

$$
F^{k} \leq C
$$

де $F^{k}$ - сумарна вартість $k$-го маршруту, грн; C - граничні експлуатаційні витрати, що допустимі при перевезенні залізничним транспортом вантажу відповідного класу небезпеки, грн.

Для розв'язання поставленої задачі запропоновано використати алгоритм Йєна, схема якого припускає застосування алгоритму Флойда-Воршелла для пошуку одного оптимального маршруту між двома вершинами на мережі.

Висновок. Одним із найбільш складних етапів в організації перевезень небезпечних вантажів на залізничному транспорті $є$ процес планування маршруту слідування вагонів, який визначає 3 урахуванням діючого плану 


\section{Експлуатація залізниць}

формування вантажних поїздів напрямок слідування та категорію поїзда, станції зупинки та розклад руху. Від рівня планування залежить безаварійність процесу перевезення небезпечних вантажів та ефективність реалізації якості заявлених послуг залізничним транспортом (точність доставки, швидкість за умови збереження вантажу).

У даній статті запропоноване вирішення науково-прикладного завдання щодо формування автоматизованої технології управління процесом просування вагонів 3 небезпечними вантажами, основу якої складає розроблена математична модель.
Формалізовано процес планування маршрутів прямування вагонів 3 небезпечними вантажами на тактичному рівні у вигляді двоетапної математичної моделі вибору найбільш безаварійного маршруту прямування вагонів 3 небезпечними вантажами, ідея якої полягає у послідовному використанні процедури Йєна-Флойда для вибору множини можливих маршрутів прямування вагонів 3 небезпечними вантажами, потужність якої обмежено встановленими критичними експлуатаційними витратами та пошуком оптимального маршруту на основі мінімізації ризиків.

\section{Список використаних джерел}

1. Дубовіч, I.А. сучасні еколого-економічні проблеми транспортування небезпечних вантажів львівською залізницею [Текст] / І.А. Дубовіч, М.В. Руда // Науковий вісник НЛТУ України. - 2012. Вип. 22.9. - С. 66-71.

2. Переста, І.Я. Забезпечення вдосконалення профілактичних заходів під час перевезення небезпечних вантажів [Текст] / І.Я. Переста, Л.О. Яришкіна, С.І. Музикіна [та ін.] // Зб. наук. праць ДНУЗТ “Транспортні системи та технології перевезень”. - Дніпропетровськ, 2011. - Вип. 2. - С. 8288.

3. Бутько, Т.В. Формування математичної моделі планування маршрутів слідування вагонів 3 небезпечними вантажами в умовах ризику [Текст] / Т.В. Бутько, О.В. Прохорченко, С.I. Музикіна // Вісник Східноукраїнського національного університету ім. Володимира Даля. - 2012. - №3(174). - С. 18-23.

4. Бутько, Т.В. Формування моделі оперативного управління процесом просування вагонів 3 небезпечними вантажами в підсистемі “технічна станція - прилегла станція” на базі нечіткої ситуаційної мережі [Текст] / Т.В. Бутько, О.В. Прохорченко, С.І. Музикіна // Інформаційно-керуючі системи на залізничному транспорті. Науково-технічний журнал. - Харків, 2012. - Вип. 3. - С. 3-8.

5. Музикіна, C.I. Питання охорони праці під час виконання вантажних операцій з небезпечними вантажами [Текст] / С.I. Музикіна, І.Я. Переста, І.Л. Журавель, В.В. Журавель // Матеріали V Міжнародної науково-практичної конференції. - К., 2011. - С. 304-305.

6. Правила перевезення небезпечних вантажів затверджені наказом Міністерства транспорту та зв’язку України від 25 листопада 2008 р. № 1430 [Текст]. Зареєстровано в Міністерстві юстиції України 26 лютого 2009 р. за 180/16196. - 120 с.

Бутько Тетяна Василівна, д-р техн. наук, професор, завідувач кафедрою управління експлуатаційною роботою Української державної академії залізничного транспорту.

Савчук Тарас Миколайович, студент Української державної академії залізничного транспорту. Е-таil: taras_savthuk_1991@mail.ru. Тел.+380667377913.

Butko T.V., Dr. tehn. science, Operation Work Management Department of Ukrainian State Academy of Railway Transport.

Savchuk TM, Master, student of Ukrainian State Academy of Railway Transport. E-mail: taras_savthuk_1991@mail.ru. Tel.+380667377913. 